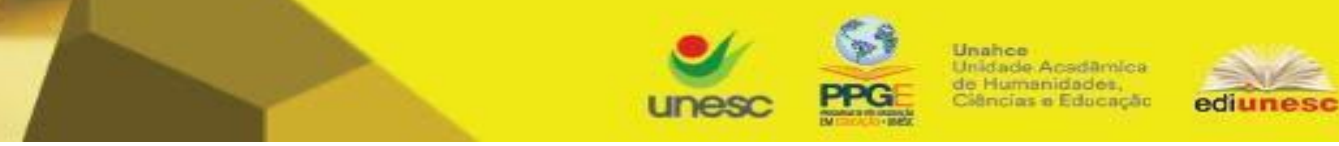

Criar Educação, Criciúma, v. 10, no1, jan/jul 2021.- PPGE - UNESC - ISSN 2317-2452

\title{
A INSERÇÃOIPERMANÊNCIA MASCULINA NA DOCÊNCIA DA EDUCAÇÃO INFANTIL
}

Sueli Almeida Chaves ${ }^{1}$

RAMOS, Joaquim. Gênero na Educação Infantil: relações (im)possíveis para professores homens. Jundiaí: Paco, 2017.

O livro escrito por Joaquim Ramos "Gênero na Educação Infantil: relações (im)possíveis para professores homens" (2017), premiado na $9^{\circ}$ edição do concurso "Construindo a igualdade de gênero" e que conta com a introdução escrita pelo Prof. Dr. Luciano Mendes de Faria Filho, é composto por três capítulos que visam apresentar os paradigmas e convergências que os "professores homens" vivenciam ao abraçar a profissão de educadores na Educação Infantil.

Impulsionado por sua militância e experiência na Educação Infantil, Joaquim Ramos pesquisou, em um dos principais municípios do Brasil, os índices de homens atuantes nas creches e pré-escolas das redes públicas municipais deste mesmo município². De acordo com Ramos, "Até o início da pesquisa que resultou neste livro (2009), havia, num universo de 1.837 docentes, apenas 14 professores do sexo masculino atuando como educadores infantis em instituições de educação infantil" (p. 24).

Visando evidenciar os motivos do ingresso e da permanência do gênero masculino na atuação com crianças de 0 a 6 anos na rede pública municipal de uma capital de grande importância sociocultural no país, e contribuindo para compreendermos as relações que estas instituições de ensino estabelecem

\footnotetext{
${ }^{1}$ Graduada no curso de licenciatura plena em Pedagogia pela Universidade Nove de Julho.

2 Por questões éticas, o autor não revela nem o estado, nem as instituições de ensino por ele examinadas.
} 
Criar Educação, Criciúma, v. 10, no1, jan/jul 2021.- PPGE - UNESC - ISSN 2317-2452

com os mesmos profissionais investigados, o autor dialoga com fatos oriundos dos movimentos sociais e feministas, atrelados aos estudos de gênero.

Para a concretização de seu trabalho, o autor realizou entrevistas com as vice-diretoras, coordenadoras pedagógicas e gerente pedagógica que atuam nas creches e pré-escolas participantes de sua pesquisa (p.37-38). No tocante aos professores lotados nas instituições que atendem crianças de 0 a 6 anos de idade na rede pública municipal do município escolhido, foram realizadas 12 entrevistas individuais, além de cinco entrevistas com três professores selecionados (p.37). Nessa etapa da pesquisa, denominada por Ramos como fase "exploratória", os debates recolhidos e analisados dos três professores foram essenciais para identificar, de maneira minuciosa e detalhada, o cotidiano dos educadores infantis proporcionando, segundo afirma o autor, captar as aspirações apontadas por estes três profissionais. Para concluir, Ramos fomentou cinco grupos de discussão compostos por 28 pessoas: 10 professoras, 4 pais, 4 avós, 1 avó, 1 irmã e 8 mães (p.38). Nessa fase, as entrevistas e discussões em grupo, realizadas com a comunidade escolar (interna e externa) $)^{3}$, da rede pública municipal analisada, possibilitou o autor constatar as diversas concepções que são formuladas a respeito da presença masculina como educadores infantis.

Dito isto, no primeiro capítulo, o autor expõe as políticas de Educação Infantil, no município pesquisado, abordando o ingresso masculino nas instituições públicas municipais que atendem creches, pré-escolas e redes conveniadas. Objetivando descrever a ocupação masculina na profissão de educador infantil, Ramos historia a luta por creches e pré-escolas no Brasil, apontando conjunturas históricas e sociais que favoreceram o ingresso do contingente feminino nas instituições de educação infantil em detrimento da mão de obra masculina. Os dados obtidos por sua pesquisa propõem discutir o

\footnotetext{
${ }^{3} \mathrm{O}$ autor caracteriza a comunidade interna escolar composta por professoras, diretoras, vice-diretoras, coordenadoras e gerente regional de educação, enquanto, pais, mães e parentes das crianças compõem a comunidade escolar externa retratada em sua obra (p.25).
} 
Criar Educação, Criciúma, v. 10, no1, jan/jul 2021.- PPGE - UNESC - ISSN 2317-2452

caráter binário e dicotômico constituinte das relações de gênero. Ou seja, se de um lado os "professores homens" inseridos em creches e pré-escolas são vistos como "fora do lugar4", Ramos nos convida a questionarmos o oposto: o porquê da docência na educação infantil em repelir a mão de obra masculina, enquanto privilegia o contingente feminino a designar a função de professora da Educação Infantil?

No capítulo segundo, são destacadas as formas de adequação dos educadores que ingressaram nas redes públicas municipais de creches e préescolas examinadas, evidenciando as peculiaridades que esses profissionais encontram ao assumirem o cargo de educadores infantis. Para além do estágio probatório, acrescenta Ramos, os recém-chegados educadores precisam provar para a comunidade escolar que não representam nenhum tipo de perigo ou de risco, principalmente em relação ao cuidado de crianças (meninas) pequenas. O "tempo gasto para que esses professores possam dar provas de suas capacidades" (p.123-124) é caracterizado pelo autor como "estágio comprobatório", acarretando segundo ele, em uma dupla exigência imposta para a aceitação dos "professores homens".

Posto isto, o trabalho de Ramos leva-nos a refletir sobre as dimensões paradoxais emergentes da presença masculina na esfera infantil, em uma dimensão educacional: a incansável investigação da sexualidade masculina. Nesse sentido, o duplo padrão que os profissionais do gênero masculino enfrentam quanto à comprovação de sua sexualidade ("homem afeminado" versus "viril indomável") foram evocadas segundo demonstraram as narrativas dos/as próprios/as docentes e dos/as demais envolvidos/as na pesquisa. Por outro lado, o autor detecta que a aceitação do gênero masculino, enquanto ser homoafetivo, é interpretada pela equipe e pelos pais/e homens responsáveis pelas crianças pequenas como algo positivo. Isto é, são positivamente aceitos por não possuírem a sexualidade exacerbada, não sendo, portanto, algozes de

\footnotetext{
${ }^{4}$ Expressão utilizada pelo autor do respectivo livro resenhado.
} 
Criar Educação, Criciúma, v. 10, no1, jan/jul 2021.- PPGE - UNESC - ISSN 2317-2452

práticas de violência sexual infantil. Nesse capítulo, Joaquim Ramos possibilita aos/as pesquisadores/as e interessados/as, nas questões de gênero nesse nível educativo, apurar as diferentes formas de como os educadores infantis são percebidos pela comunidade escolar e pelas crianças destas instituições de ensino, além de proporcionar reflexões referentes às construções identitárias dos mesmos.

Por fim, o terceiro capítulo sintetiza a forma como os professores infantis são vistos e reconhecidos por todos/as os/as membros da comunidade escolar por ele estudada. Os julgamentos descritos pelos/as entrevistados/as e recolhidos nos debates, são sustentados pelo senso comum e facilitam clarificar o modo como esses sujeitos compreendem as relações de gênero. A saber, as discussões mantidas pelos/as participantes desta pesquisa, beneficiam o essencialismo das identidades masculina e feminina, ao mesmo tempo em que naturalizam as desigualdades de gênero. Debatendo o imaginário popular criado em torno das questões que englobam gênero e sexualidade, Ramos novamente detecta a unanimidade retratada na narrativa dos/as entrevistados/as quanto à indissociação entre gênero e sexualidade. Empregados pela comunidade escolar como sinônimo, gênero é atrelado à sexualidade, assim como a sexualidade é atrelada às questões de gênero. Com isso, o autor explicita o pavor constante da comunidade escolar por permitir a frequência de um professor do gênero masculino na Educação Infantil.

O trabalho de Joaquim Ramos instiga e convida os/as profissionais e interessados/as nas relações de gênero, nessa etapa educacional, a indagar sobre os caminhos a serem percorridos para a consolidação de uma educação inclusiva, que vivencie, com respeito e reconhecimento, as diversas formas de ser, agir e pensar que constituem a multiplicidade do ser social. Afinal, como proporcionaremos, enquanto educadoreslas, que as futuras gerações se encarreguem de constituir uma sociedade democrática, se a comunidade 
Criar Educação, Criciúma, v. 10, nº1, jan/jul 2021.- PPGE - UNESC - ISSN 2317-2452

escolar não encorajar seus membros a refletirem a respeito de que parte desta violência de gênero eclode também na própria equipe pedagógica? Portanto, para que a diferença não seja tida como contraria a igualdade, as discussões de gênero na Educação Infantil, propostas na produção do pesquisador, vinda à luz há dois anos, colaboram imensuravelmente, tanto para desmistificar a masculinidade e feminilidade como identidades fixas e imutáveis, tanto por seu compromisso em acalorar, no interior das instituições que atendem crianças de 0 a 6 anos, a ratificação da manutenção destas mesmas desigualdades. 